\title{
PENGEMBANGAN E-LEARNING MATA KULIAH APLIKASI KOMPUTER 2 DI PROGRAM STUDI PENDIDIKAN SEJARAH UNIVERSITAS FLORES
}

\author{
Kristina Sara, Mukminan \\ FKIP Univesitas Flores, Universitas Negeri Yogyakarta \\ kristina_27id@yahoo.com,mukminan@yahoo.co.id
}

\begin{abstract}
Abstrak
Tujuan penelitian ini adalah untuk menghasilkan e-learning mata kuliah Aplikasi Komputer 2 di Program Studi Pendidikan Sejarah Universitas Flores yang berkualitas baik dan efektif. Penelitian ini merupakan penelitian pengembangan yang mengembangkan media pembelajaran e-learning mata kuliah Aplikasi Komputer 2 dengan menggunakan model pengembangan dari Allesi \& Trollip melalui tahap perencanaan, desain, dan pengembangan. Penelitian ini menghasilkan produk berupa e-learning mata kuliah Aplikasi Komputer 2. Hasil uji coba produk menunjukkan bahwa produk e-learning mata kuliah Aplikasi Komputer 2 yang dikembangkan layak dan efektif. Kelayakan mencapai hasil sangat baik ditinjau dari penilaian ahli materi dengan skor 4,31, ahli media dengan skor 3,46, dan tanggapan mahasiswa dengan skor 4,43. Keefektivan pembelajaran Aplikasi Komputer 2 menggunakan e-learning terbukti secara signifikan dapat meningkatkan hasil belajar kognitif mahasiswa dengan rerata pretest 57,38 dan posttest 85,50 sehingga perolehan hasil effect size adalah 28,13 . Pencapaian ketuntasan hasil belajar pada saat pretest $56,25 \%$ tuntas dan saat posttest $100 \%$ tuntas.
\end{abstract}

Kata kunci: pengembangan, e-learning

\section{DEVELOPING E-LEARNING FOR COURSE OF COMPUTER APPLICATION 2 IN THE HISTORY STUDY PROGRAM UNIVERSITY OF FLORES}

\author{
Kristina Sara, Mukminan \\ FKIP Univesitas Flores, Universitas Negeri Yogyakarta \\ kristina_27id@yahoo.com, mukminan@yahoo.co.id
}

\begin{abstract}
This study aims to produce an e-learning course in Computer Applications 2 Educational Studies Program University History Flores are good quality and effective. This research is the development of instructional media to develop e-learning for courses of Computer Applications 2 by using the development model of Allesi \& Trollip through the planning, design, and development. This research resulted in a product form of e-learning courses Computer Applications 2. This can be seen from the results of the appropriateness testing showing that from the material aspect they are in the good category with a mean of 4.31, according to the media expert they are in the good category with a mean of 3.46, and according to students' responses they are in the very good category with a mean of 4.43. The effectiveness of e-learning materials for Computer Application 2 is proved by the fact that they are capable of improving students' learning outcomes. The students' cognitive learning outcomes showed a pretest mean of 57.38 and a posttest mean of 85.50, so that the effect size was 28.13. The attainment of the mastery of the students' cognitive learning outcomes in the pretest was $56.25 \%$ and that in the posttest was $100 \%$.
\end{abstract}

Keywords: development, e-learning 


\section{Pendahuluan}

Perkembangan teknologi informasi yang sangat pesat telah memiliki peranan yang dapat dimanfaatkan untuk berbagai kepentingan termasuk didalamnya untuk pendidikan atau pembelajaran. Internet merupakan hasil dari perkembangan teknologi informasi yang tentunya memiliki pengaruh dalam dunia pendidikan. Secara tidak langsung internet mendorong dunia pendidikan untuk menyesuaikan dengan arus informasi globalisasi, secara langsung internet dapat dimanfaatkan sebagai sumber dan media pembelajaran bagi mahasiswa dalam mengembangkan ilmu pengetahuan.

Internet merupakan sebuah perpustakaan rakasasa dunia yang didalamnya terdapat jutaan bahkan miliaran informasi atau data yang dapat berupa text, grafic, audio, animasi maupun digital konten lainnya (Rusman, Kurniawan, \& Riyana, 2012, p.48). Internet memberikan kemudahan memperoleh informasi dengan mudah, efektif, dan efisien. Penggunaan fasilitas internet yang kurang efektif mendorong lahirnya suatu desain pembelajaran yang mampu melebihi pembelajaran yang ada saat ini. Fasilitas internet saat ini semestinya tidak hanya digunakan sebagai media hiburan dan media sosial semata, tetapi dapat digunakan untuk melakukan konsultasi masalah belajar, pemberian tugas, ujian, dan menciptakan kegiatan layanan secara interaktif antara dosen dan mahasiswa dalam melakukan pengembangan bahan ajar bagi kepentingan pembelajaran.

Salah satu bentuk penerapan teknologi informasi dalam pembelajaran melalui internet adalah e-learning. (Clark \& Mayer, 2011, p.8) menyatakan bahwa e-learning adalah "Instruction delivered on a digital device such as a computer or mobile device that is intended to support learning", yang berarti e-learning adalah pembelajaran yang disampaikan melalui perangkat digital seperti komputer atau alat elektronik lain yang dimaksudkan untuk mendukung proses belajar. Proses pembelajaran menggunakan e-learning terdiri dari pesan dan teknik pembelajaran yang membantu mahasiswa dalam belajar. Proses penyampaian pesan pembelajaran dapat melalui perangkat elektronik atau mobile seperti computer tablet bahkan smart phone dan berbentuk multimedia yang dapat di akses dari mana saja dan kapan saja. E-learning juga merupakan jaringan dengan kemampuan untuk memperbaharui, menyimpan, mendistribusi, dan membagi materi ajar atau informasi. Dengan e-learning mahasiswa dapat mengambil materi-materi yang telah di upload oleh dosen yang bersangkutan, untuk memudahkan proses belajar mahasiswa dalam meningkatkan kemampuannya.

Program Studi Pendidikan Sejarah merupakan wadah untuk: (1) menghasilkan tenaga pendidik sejarah yang profesional, berdaya saing tinggi, berkarakter kuat dan cerdas; (2) menghasilkan tenaga pendidik sejarah yang memiliki kemampuan meneliti dan inovasi di bidang pendidikan sejarah; (3) menghasilkan tenaga pendidik sejarah yang memiliki kemampuan mendesiminasikan hasil pengembangan dan inovasi di bidang pendidikan sejarah melalui kegiatan pengabdian pada masyarakat dan kerjasama dengan institusi lain; (4) menghasilkan instruktur/peman$\mathrm{du}$ wisata sejarah yang terampil dengan mengacu pada nilai budaya lokal dan budaya nasional dalam menghadapi era globalisasi.

Salah satu mata kuliah pada Program Studi Pendidikan Sejarah Universitas Flores yang harus dikuasai kompetensinya oleh mahasiswa yaitu mata kuliah Aplikasi Komputer 2 (AK2). Mata kuliah AK2 merupakan mata kuliah praktikum yang mempelajari tentang perangkat lunak komputer Microsoft Powerpoint dengan tujuan, setelah mahasiswa mendapatkan pembelajaran AK2, diharapkan mampu membuat presentasi dengan memanfaatkan perangkat lunak Microsoft Powerpoint. Teknik dan strategi yang digunakan dalam pembelajaran AK2 sebaiknya mempertimbangkan tujuan program, tujuan-tujuan yang hendak dicapai, dan kemampuan mahasiswa dalam memanfaatkan perangkat lunak komputer. 
Mahasiswa Program Studi Pendidikan Sejarah yang juga merupakan calon pendidik, diharapkan setelah lulus dan bekerja pada salah satu instansi pendidikan mampu membuat bahan ajar yang menarik dalam proses pembelajaran. Dengan bahan ajar yang menarik, peserta didik lebih berminat untuk belajar, sehingga pada akhirnya bisa meningkatkan hasil belajar bagi peserta didik. Salah satu cara membuat bahan ajar yaitu membuat media pembelajaran interaktif dan kuis interaktif dengan memanfaatkan perangkat lunak komputer Microsoft Powerpoint. Dengan adanya media pembelajaran interaktif, maka peserta didik bisa belajar sendiri dan mengukur kemampuan belajarnya lewat kuis interaktif.

Berdasarkan hasil wawancara dengan dosen mata kuliah AK2 di Program Studi Pendidikan Sejarah Universitas Flores, selama ini dalam pembelajaran AK2 disampaikan melalui media cetak yaitu berupa modul yang telah disediakan oleh pihak laboratorium komputer Universitas Flores. Materi yang disampaikan dalam modul tersebut hanya sampai sebatas memanfaatkan Microsoft Powerpoint sebagai alat dalam pembuatan presentasi.

Sarana dan prasarana, laboratorium komputer kampus yang cukup memadai, lengkap dengan internet belum dimanfaatkan secara optimal sebagai media pembelajaran. Padahal, secara umum mahasiswa telah mempunyai keterampilan dasar mengoperasikan komputer karena para mahasiswa telah mendapatkan pelajaran Teknologi Informasi dan Komunikasi (TIK) dari Sekolah Menengah Pertama (SMP) sampai Sekolah Menengah Atas (SMA).

Solusi untuk mengatasi permasalahan yang ada, peneliti mengembangkan e-learning mata kuliah AK2 dan menambahkan materi tentang (1) membuat media pembelajaran interaktif dengan Microsoft Powerpoint 2007, dan (2) membuat kuis interaktif dengan Microsoft Powerpoint 2007. Penambahan materi ini bertujuan untuk menambahkan wawasan dan meningkatkan kemampuan bagi mahasiswa tentang kegunaan dari Microsoft Powerpoint, sehing- ga diharapkan setelah mahasiswa tersebut lulus dari perguruan tinggi dan bekerja di instansi pendidikan, akan mampu mengembangkan bahan ajar dengan menggunakan Microsoft Powerpoint untuk digunakan dalam proses pembelajaran.

Dalam kaitannya dengan pembelajaran mata kuliah AK2, dukungan produk e-learning dalam proses pembelajaran dapat meningkatkan motivasi belajar mahasiswa. Penggunaan produk e-learning juga dapat memungkinkan mahasiswa untuk belajar secara mandiri mencari bahan dan informasi sesuai minat masing-masing tanpa adanya intervensi dari siapapun. (Daryanto, 2010, p.168). Untuk mendukung hal tersebut, penggunaan produk e-learning sangat diperlukan untuk menyampaikan dan memperjelas konsep yang ada serta membantu dosen dalam memberikan model pembelajaran kepada mahasiswa.

Pemilihan e-learning sebagai media pembelajaran dengan memakai internet delivery karena memiliki beberapa alasan, sebagaimana dikatakan (Lee \& Owens, 2005, p.191) sebagai berikut: (a) universal access, yaitu semua orang dapat mengakses web dengan web browser dan modem. Setiap orang dapat menyampaikan suatu materi dari mana saja di seluruh dunia, (b) easy of use, software internet dan intranet mudah digunakan, mudah dijangkau pengguna secara luas dengan pengalaman komputer yang terbatas sekalipun, dan (c) multimedia content, yaitu teknologi ini didukung multimedia sebagai pengantar pesan secara menarik, sehingga dapat memfasilitasi belajar berbagai pengguna dengan gaya belajar yang berbeda-beda.

Pembelajaran e-learning merupakan pembelajaran dengan menggunakan jasa bantuan perangkat elektronik, khususnya perangkat komputer. Proses pembelajaran ini didukung oleh jasa teknologi seperti komputer, jaringan internet, dan media graphic audio visual. E-learning secara sederhana dapat dipahami sebagai suatu proses pembelajaran yang memanfaatkan teknologi informasi berupa komputer yang dilengkapi dengan sarana telekomunikasi (internet, intranet, ekstranet) dan multimedia 
(grafis, audio, video) sebagai media utama dalam penyampaian materi dan interaksi antara dosen dan mahasiswa. Pengembangan e-learning dilembaga pendidikan bertujuan untuk meningkatkan efektivitas dan fleksibilitas pembelajaran. Menurut (Surjono, 2010, p.3) banyak hasil penelitian menunjukkan bahwa efektivitas pembelajaran menggunakan e-learning cenderung sama bila dibanding dengan pembelajaran konvensional atau klasikal, tetapi keuntungan yang bisa diperoleh dengan e-learning adalah dalam hal fleksibilitasnya.

\section{Metode Penelitian}

Penelitian ini merupakan penelitian pengembangan. Penelitian difokuskan pada pengembangan produk yang berupa $e$ learning mata kuliah Aplikasi Komputer 2. Model pengembangan yang digunakan dalam penelitian ini adalah model dari Allesi \& Trollip. Materi mata kuliah Aplikasi Komputer 2 yang dikembangkan adalah (1) membuat presentasi, (2) membuat media pembelajaran interaktif dan (3) membuat kuis interaktif dengan memanfaatkan Microsoft Powerpoint.

Dalam pengembangan e-learning mata kuliah Aplikasi Komputer 2 memiliki 3 tahap, yaitu tahap perencanaan, desain, dan pengembangan. Tahap Perencanaan (Planning), yang dilakukan dalam tahap ini sebagai berikut: (a) mendefinisikan ruang lingkup penelitian (define the scope), Materi yang akan dikembangkan adalah materi mata kuliah aplikasi komputer 2 dengan standar kompetensi (SK) yaitu memanfaatkan perangkat lunak komputer (Microsoft Powerpoint) untuk mempermudah pekerjaan dalam menyampaikan materi berupa presentasi, dan membuat media pembelajaran interaktif. Kompetensi dasar yaitu (1) membuat presentasi dengan Microsoft Powerpoint 2007, (2) membuat media pembelajaran interaktif dengan Microsoft Powerpoint 2007, (3) membuat kuis interaktif dengan Microsoft Powerpoint 2007; (b) mengidentifikasi karakteristik mahasiswa (Identify learner characteristics), dari hasil wawancara dan observasi pra survey. Maka dila- kukan sebagai berikut: menganalis bukubuku Aplikasi Komputer 2 yang digunakan mahasiswa semester 4 Program Studi Pendidikan Sejarah, Menganalisis sumbersumber belajar yang ada di kampus dan lingkungan mahasiswa, Menganalisis sarana dan prasana penunjang pembelajaran, Menganalisis metode dan pendekatan serta strategi pembelajaran yang ditetapkan dalam proses pembelajaran serta kendalakendala yang dihadapi dosen dan mahasiswa terkait dengan sumber belajar, motede, pendekatan dan strategi yang digunakan. Informasi ini dikumpulkan dengan menggunakan instrumen kuesioner dan wawancara analisis kebutuhan. Hasil analisis kebutuhan ini akan digunakan sebagai acuan dalam desain pengembangan e-learning mata kuliah Aplikasi Komputer 2, sehingga produk yang dihasilkan dapat bermanfaat. (c) Menentukan dan mengumpulkan sumber belajar (determine and collect resources) untuk mata kuliah AK2, misalnya: dari buku, jurnal, internet, dan lain-lain.

Tahap Desain (Design), pada tahap ini, aktivitas yang dilakukan berhubungan dengan pengaturan isi atau content yang akan di upload ke e-learning. Tahap ini terdiri dari dua langkah, yaitu: (1) melakukan analisis konsep dan tugas (conduct task and concept analysis) yang berkaitan dengan materi Aplikasi Komputer 2 semester 4 dengan langkah-langkah sebagai berikut: (a) Analisis pembelajaran, yang dilakukan antara lain: menetapkan materi pembelajaran, menulis standar kompetensi materi pembelajaran, menulis kompetensi dasar yang akan dicapai, merumuskan indikator keberhasilan, membuat alat pengukur keberhasilan; (b) membuat desain pembelajaran yang terdiri dari kompetensi dasar; (c) pengumpulan bahan berupa teks dan gambar, dari berbagai sumber; (2) membuat struktur program pengembangan $e$ learning mata kuliah Aplikasi Komputer 2 atau flowchart.

Tahap Pengembangan (Development) Pada tahap ini aktifitas yang dilakukan terdapat enam langkah yaitu: (1) membangun portal e-learning dengan meng- 
gunakan LMS Moodle. Membangun suatu portal e-learning di perlukan tempat atau server di internet dan nama domain atau alamat (URL). Server berfungsi dapat diakses melalui internet dengan alamat tertentu (URL), setelah mempunyai portal elearning, ada beberapa peran dan tugas user pada e-learning ini yaitu sebagai administrator, couse creator, teacher, non-editing teacher, student, guest dan authenticated user. Peneliti di sini akan melakukan peran dan tugas sebagai teacher, course creator dan administrator. Peran tersebut untuk dapat mengembangkan e-learning yang sesuai dengan kebutuhan dan karakteristik mahasiswa yang menjadi target $u s e r$. Tugas yang dilakukan oleh peneliti setelah mendapatkan domain adalah mengubah identitas $e^{-}$ learning, mengubah thema, membuat kategori dan membuat user; (2) menyiapkan teks (prepare the text) yang akan dijadikan content e-learning, content e-learning yang akan di upload dipersiapkan dalam bentuk file PDF dan Powerpoint. E-learning mata kuliah Aplikasi Komputer 2 yang dikembangkan ini terdiri dari 3 kompetensi dasar; (3) menggabungkan bagian-bagian (assemble the pieces), menggabungkan teks dan grafis yang telah diseleksi dan dipersiapkan, untuk mata kuliah Aplikasi Komputer 2. Selama menggabungkan teks dan grafis menjadi bahan ajar Aplikasi Komputer 2 ini dilakukan evaluasi berkelanjutan (ongoing evaluation) walaupun tidak formal; (4) menyiapkan materi-materi pendukung (prepare support material). Materi-materi pendukung dipersiapkan dalam bentuk animasi, tugas, latihan, aktivitas praktikum, dan uji kompetensi untuk masing-masing kompetensi dasar. Animasi ditampilkan dengan cara link ke URL yang menyediakan animasi pendukung bahan ajar Aplikasi Komputer 2 yang dikembangkan. Alamat URL yang menampilkan animasi dipilih peneliti sebagai materi pendukung, bisa selalu diupdate setiap saat; (5) evaluasi formatif, yang dilakukan melalui dua tahap yaitu uji alpha dan uji beta (a) Uji alpha, melibatkan dua orang ahli materi yang menekuni keilmuan Aplikasi Komputer 2 dan dua orang ahli media de- ngan kriteria memiliki kompetensi mengenai media pembelajaran. (b) Uji beta yang melibatkan tiga orang mahasiswa semester empat Program Studi Pendidikan Sejarah Universitas Flores dengan tingkat kemampuan tinggi, sedang dan rendah, kemudian dianalisis dan dilakukan revisi akhir. (6) Evaluasi Sumatif/Uji Coba Program, yakni menggunakan e-learning dalam proses pembelajaran Aplikasi Komputer 2 dikelas, pada subjek uji coba seluruh mahasiswa kelas B Program Studi Pendidikan Sejarah Universitas Flores. Dalam tahap ini dilakukan pengumpulan data tentang kesan setelah mahasiswa belajar mata kuliah Aplikasi Komputer 2 melalui lembar angket dan menilai hasil belajar mereka melalui pemberian soal pretest dan posttest.

Uji coba pada penelitian ini terdiri dari 3 tahap, yaitu, (1) uji alpha/validasi ahli yang mana hasil validasi akan dijadikan bahan untuk merevisi produk awal. (2) uji beta dilakukan untuk menguji apakah kualitas e-learning mata kuliah Aplikasi Komputer 2 yang dihasilkan telah terpenuhi dari segi layak dan efektif. Tindakan yang dilakukan adalah dengan meminta penilaian dari 3 orang mahasiswa Program Studi Pendidikan Sejarah yang dipilih berdasarkan kemampuan akademik yaitu tinggi, sedang, dan kurang. Mahasiswa tersebut diminta untuk mengerjakan pretest, membuka dan mempelajari e-learning mata kuliah Aplikasi Komputer 2, kemudian diminta memberikan komentar/masukan tentang produk e-learning tersebut. Berdasarkan masukan tersebut dilakukan revisi terakhir terhadap produk, maka diperoleh produk yang siap digunakan pada uji coba produk. Selama proses pengembangan e-learning mata kuliah AK2 dilakukan ongoing evaluation.

Subjek uji coba adalah mahasiswa kelas B Program Studi Pendidikan Sejarah Universitas Flores tahun ajaran 2013 yang berjumlah 16 orang. Uji coba produk dilaksanakan pada bulan Juni-Juli 2013.

Jenis data dalam penelitian ini adalah data kualitatif dan data kuantitatif. Data kualitatif diperoleh dari komentar dan saran para ahli, sedangkan data kuantitatif 
diperoleh dari hasil validasi oleh ahli materi, ahli media, dan mahasiswa. Data kuantitatif berupa skor, selanjutnya dianalisis dan dikonversikan ke dalam bentuk data kualitatif. Hasil konversi tersebut kemudian menjadi tolak ukur untuk menentukan kelayakan pengembangan e-learning mata kuliah AK2. Data penilaian hasil belajar diperoleh dari hasil pretest dan posttest berupa data kuantitatif.

Instrumen atau alat pengumpulan data yang digunakan berupa observasi, wawancara, lembar angket (untuk validasi ahli materi dan ahli media serta lembar angket untuk penilaian atau tanggapan uji coba produk).

Data hasil penelitian ini adalah berupa tanggapan ahli materi, ahli media dan mahasiswa terhadap kualitas produk yang telah dikembangkan ditinjau dari aspek materi dan aspek media. Data berupa komentar, saran, revisi, dan hasil pengamatan peneliti selama proses uji coba dianalisis secara deskriptif kualitatif, dan disimpulkan sebagai masukan untuk memperbaiki atau merevisi produk yang telah dikembangkan.

Sementara, data berupa skor tanggapan ahli materi, ahli media dan mahasiswa yang diperoleh melalui kuesioner, dianalisis secara deskriptif kuantitatif dengan teknik persentase dan kategorisasi. Langkah-langkah yang digunakan untuk menentukan kriteria kualitas produk yang telah dikembangkan, sebagai berikut: (a) Data yang diperoleh dari kuesioner tentang tanggapan mahasiswa diubah dulu menjadi data interval sebagai berikut: Sangat Baik $=5(100 \%$ sesuai dengan unsur-unsur yang ada dalam pertanyaan/pernyataan itu), Baik $=4(80 \%$ sesuai dengan unsurunsur yang ada dalam pernyataan/pernyataan itu), Cukup Baik $=3(60 \%$ sesuai dengan unsur-unsur yang ada dalam pernyataan/pernyataan itu), Kurang Baik $=2$ (40\% sesuai dengan unsur-unsur yang ada dalam pernyataan/pernyataan itu), Sangat Kurang baik $=1(20 \%$ sesuai dengan unsurunsur yang ada dalam pernyataan/pernyataan itu).
Data kuesioner diberikan lima pilihan untuk memberikan tanggapan tentang e-learning mata kuliah AK2 yang dikembangkan, yaitu; sangat baik (5), baik (4), cukup baik (3), kurang baik (2), dan sangat kurang baik (1). Seandainya mahasiswa memberi tanggapan "sangat baik" pada suatu butir pertanyaan/pernyataan, maka skor butir pertanyaan tersebut sebesar " 5 ", demikian seterusnya. Skor yang diperoleh, kemudian dikonversikan menjadi kualitatif skala lima, dengan acuan rumus yang dikutip dari Sukardjo (2006, p.53) dapat dilihat pada Tabel 1 .

Tabel 1. Konversi Skor Aktual menjadi Nilai Skala Lima

\begin{tabular}{cll}
\hline Nilai & Skor & \\
\hline $\mathrm{A}$ & $\mathrm{Xi}_{\mathrm{i}}+1,80 \mathrm{SB}_{\mathrm{i}}$ & $<\mathrm{X}$ \\
$\mathrm{B}$ & $\mathrm{Xi}_{\mathrm{i}}+0,60 \mathrm{SB}_{\mathrm{i}}$ & $<\mathrm{X} \leq \mathrm{Xi}+1,80 \mathrm{SB}_{\mathrm{i}}$ \\
$\mathrm{C}$ & $\mathrm{Xi}_{\mathrm{i}}-0,60 \mathrm{SB}_{\mathrm{i}}$ & $<\mathrm{X} \leq \mathrm{Xi}+0,60 \mathrm{SB}_{\mathrm{i}}$ \\
$\mathrm{D}$ & $\mathrm{Xi}-0,80 \mathrm{SB}_{\mathrm{i}}$ & $<\mathrm{X} \mathrm{Xi}-0,60 \mathrm{SB}_{\mathrm{i}}$ \\
$\mathrm{E}$ & & $\mathrm{X} \leq \mathrm{Xi}-0,80 \mathrm{SB}_{\mathrm{i}}$ \\
\hline
\end{tabular}

Keterangan:

Rerata skor ideal $(\mathrm{Xi}): \frac{1}{2}$ (skor maksimal ideal + skor minimal ideal)

Simpangan baku skor ideal (SBi) : $\square$ (skor maksimal ideal + skor minimal ideal)

$X$ : Skor aktual

Tabel 2. Konversi Rerata Skor menjadi Kriteria untuk Menilai Kualitas Produk Elearning Mata Kuliah AK2

\begin{tabular}{cll}
\hline Nilai & Kategori & Interval Rerata Skor \\
\hline 5 & Sangat baik & $4,2<\mathrm{X}$ \\
4 & Baik & $3,4<\mathrm{X} \leq 4,2$ \\
3 & Cukup baik & $2,6<\mathrm{X} \leq 3,4$ \\
2 & Kurang baik & $1,8<\mathrm{X} \leq 2,6$ \\
1 & Sangat kurang baik & $\mathrm{X} \leq 1,8$ \\
\hline
\end{tabular}

Data tes menggambarkan keefektifan pengembangan e-learning mata kuliah AK2 untuk pembelajaran dilihat dari aspek koginitif yaitu: seberapa besar persentase mahasiswa yang telah mencapai Kriteria Ketuntasan Minimal (KKM) dan nilai kebermaknaan belajar (effect size). KKM pada mata kuliah AK2 ditentukan sebesar 60. Penentuan KKM disesuaikan dengan aturan penilaian yang berlaku di Universitas Flores. Jika mahasiswa telah mencapai 
nilai 60 artinya mahasiswa tersebut telah tuntas.

Data tentang kebermaknaan belajar dianalisis secara deskriptif yaitu dengan membandingkan antara skor pretest dengan hasil skor posttest. Menurut Olejnik dan Algina dalam Agung (2010, p.3) menyatakan bahwa effect size merupakan ukuran mengenai besarnya efek suatu variabel pada variabel lain, besarnya perbedaan maupun hubungan yang bebas dari pengaruh besarnya sampel.

Effect size juga dapat dianggap sebagai ukuran mengenai kebermaknaan hasil penelitian dalam tataran praktis. Arikunto (2006, p.275) menjelaskan rumus untuk mengetahui besarnya effect size sebagai berikut:

$$
t=\frac{M d}{\sqrt{\frac{\sum x^{2} d}{N(N-1)}}}
$$

Keterangan:

Md : mean dari perbedaan tes 1 dengan tes 2 . $\mathrm{Xd}$ : deviasi masing-masing subyek $(\mathrm{d}-\mathrm{Md})$.

D : gain (tes 2 -tes 1 ).

$\sum x^{2}$ : jumlah kuadrat deviasi.

$\mathrm{N}$ : subjek pada sampel.

d.b : ditentukan dengan $\mathrm{N}-1$.

Rumus di atas digunakan untuk menghitung besarnya effect size pada penelitian kuasi eksperimen dengan menggunakan kelas kontrol dan kelas eksperimen. Akan tetapi, pada penelitian ini uji tes sumatif dilakukan hanya dengan satu kelas eksperimen tanpa menggunakan kelas kontrol, sehingga untuk menghitung besarnya effect size pada penelitian ini hanya melibat d (gain). Arikunto (2006, p.277) nilai d diperoleh dari:

$$
\mathrm{ES}=\mathrm{d}=\overline{\mathrm{X}}_{2}-\overline{\mathrm{X}}_{1}
$$

Keterangan:

ES : effect size.

$\mathrm{D}$ : gain.

$\overline{X_{1}}$ : nilai rata-rata pretest.

$\overline{X_{2}}$ : nilai rata-rata posttest

\section{Hasil Penelitian dan Pembahasan}

Pada tahap perencanaan akan diuraikan empat kegiatan yang dilakukan sebagai berikut : (a) Mendefenisikan ruang lingkup penelitian, yaitu menetapkan standar kompetensi dan kompetensi dasar. Standar kompetensi yang dikembangkan adalah memanfaatkan perangkat lunak komputer (Microsoft Powerpoint) untuk mempermudah pekerjaan dalam menyampaikan materi berupa presentasi, dan membuat media pembelajaran interaktif. Kompetensi dasar yang dikembangkan dalam mata kuliah AK2 adalah (1) membuat presentasi dengan Microsoft Powerpoint 2007, (2) membuat media pembelajaran interaktif dengan Microsoft Powerpoint 2007, (3) membuat kuis interaktif dengan Ms. Powerpoint 2007. (b) Mengidentifikasi karakteristik mahasiswa, karakteristik mahasiswa Program Studi Pendidikan Sejarah yang sudah mampu menggunakan komputer, dan juga tertarik untuk belajar melalui komputer. (c) Menentukan dan mengumpulkan sumber belajar yang digunakan, sumber-sumber atau referensi yang dijadikan acuan dalam proses pengembangan e-learning mata kuliah Aplikasi Komputer 2. Referensi dan URL yang dapat dijadikan acuan untuk pengembangan konten e-learning mata kuliah AK2, baik dalam bentuk teks, gambar dan animasi yang diperoleh dari buku dan internet. (d) Melakukan brainstorming, melakukan diskusi dengan dosen pengajar mata kuliah Aplikasi Komputer 2 dan teman-teman sejawat sebagai expert judgment, mengenai konten yang akan dikembangkan.

Pada tahap desain, peneliti melakukan analisis konsep dan tugas yang berkaitan dengan topik, pembuatan flowchart, pembuatan layout tampilan depan e-learning AK2, pengumpulan sumber-sumber untuk mengisi konten, menentukan software yang digunakan; (a) melakukan analisis konsep dan tugas, yaitu dengan menentukan indikator yang ingin dicapai dan pembuatan RPP serta Silabus; (b) pembuatan flowchart, Bertujuan untuk menggambarkan alur pendaftaran supaya meng- 
akses e-learning dan alur untuk masuk ke course mata kuliah AK2.

Produk yang dihasilkan dalam penelitian ini adalah berupa e-learning mata kuliah AK2 (Microsoft Powerpoint). Peneliti mengembangkan e-learning mata kuliah AK2 dengan materi: (1) membuat presentasi dengan Microsoft Powerpoint 2007, (2) membuat media pembelajaran interaktif dengan Microsoft Powerpoint 2007, (3) membuat kuis interaktif Microsoft Powerpoint. Peneliti juga memanfaatkan sumber-sumber belajar dari internet untuk menunjang proses pembelajaran Aplikasi Komputer 2. Alamat dari media yang dikembangkan bisa diakses melalui www.e-uniflor.web.id/ elearning.

\section{Hasil Uji Coba Produk}

Data diperoleh dari tiga kegiatan uji coba yang dilakukan, yaitu dari data uji Alfa, data uji coba beta, dan data hasil uji coba produk. Data uji coba ahli/validasi ahli dilakukan untuk menilai atau menentukan kevalidan e-learning mata kuliah Aplikasi Komputer 2 yang dihasilkan, serta meminta masukan atau komentar dari beberapa ahli. Data yang diperoleh berupa data kuantitatif, yaitu skor penilaian ahli dan data kualitatif berupa saran atau masukan yang akan digunakan untuk memperbaiki produk. Data uji alfa terdiri dari: (1) terdapat dua orang ahli teknologi pembelajaran sebagai ahli materi. Dengan berpedoman hasil konversi rerata skor pada tabel 2, dapat disimpulkan bahwa penilaian dari kedua ahli materi terhadap keseluruhan instrumen diperoleh rerata penilaian sebesar 4,31 dalam kategori sangat baik, oleh karena itu dari sisi materi dinyatakan "layak" diujikan pada tes berikutnya yaitu uji beta; (2) terdapat dua orang ahli teknologi pembelajaran sebagai ahli media. Penilaian dari ahli media terhadap keseluruhan instrumen diperoleh skor sebesar 3,46 dalam kategori baik, oleh karena itu dari sisi materi dinyatakan "layak" diujikan pada tes berikutnya yaitu uji beta.

Kemudian data uji coba beta dilakukan dengan melibatkan 3 orang maha- siswa kelas A Program Studi Pendidikan Sejarah Universitas Flores yang dipilih berdasarkan kemampuan akademik secara heterogen, yaitu tinggi, sedang, dan rendah untuk membaca atau mengamati produk $e$ learning mata kuliah Aplikasi Komputer 2 yang dihasilkan. Jumlah skor penilaian berdasarkan data uji beta yang melibatkan tiga orang mahasiswa dengan 20 indikator adalah 260, sehingga rerata hasil penilaian berdasarkan uji beta tersebut adalah 4,33. Mengacu pada tabel konversi, hasil penilaian e-learning mata kuliah Aplikasi Komputer 2 dari mahasiswa termasuk dalam kategori sangat baik. Pada uji beta ini dilakukan juga pretest dan posttest untuk mengetahui kemampuan atau hasil belajar dari mata kuliah Aplikasi Komputer 2 dengan menggunakan e-learning.

Selanjutnya uji coba produk melibatkan 16 mahasiswa kelas B Program Studi Pendidikan Sejarah Universitas Flores. Mahasiswa diminta untuk menggunakan e-learning dengan cara membuka menu-menu yang tersedia, melihat dan mempelajari materi dan mengerjakan latihan, yang kemudian mahasiwa diminta tanggapannya dengan cara mengisi kuesioner yang telah diberikan. Jumlah skor penilaian berdasarkan data uji coba program dengan 20 indikator adalah 1416, sehingga rerata hasil penilaian berdasarkan uji beta tersebut adalah 4,43. Mengacu pada tabel konversi, hasil penilaian e-learning mata kuliah Aplikasi Komputer 2 dari mahasiswa termasuk dalam kategori sangat baik.

Pada uji coba program dilakukan juga pretest dan posttest dengan soal pilihan ganda dan tes praktikum untuk mengetahui kemampuan atau hasil belajar dari mata kuliah Aplikasi Komputer 2 dengan menggunakan e-learning.

\section{Analisis Data}

Validasi ahli materi dilakukan oleh dua orang dosen ahli materi yang meliputi aspek lingkup pembelajaran dengan 6 aspek penilaian, informasi tambahan dengan 1 aspek penilaian, pendalaman materi dengan 8 aspek penilaian, dan penilaian 
dengan 1 aspek penilaian. Berdasarkan perhitungan keseluruhan rerata hasil validasi dari kedua ahli materi adalah 4,31. Hasil ini menunjukkan bahwa kelayakan materi Aplikasi Komputer 2 adalah "Baik", sehingga dapat dilanjutkan ke tahap uji beta dengan terlebih dahulu melakukan revisi awal sesuai yang disarankan. Hasil tentang penilaian dari kedua ahli materi dapat dilihat pada Tabel 3.

Tabel 3. Hasil Validasi Ahli Materi

\begin{tabular}{llcc}
\hline No & \multicolumn{1}{c}{ Kategori } & Frekuensi & $\begin{array}{c}\text { Persentase } \\
(\%)\end{array}$ \\
\hline 1 & Sangat Baik & 10 & $31 \%$ \\
2 & Baik & 22 & $69 \%$ \\
3 & Cukup Baik & - & - \\
4 & Kurang Baik & - & - \\
5 & Sangat Kurang Baik & - & - \\
\hline \multicolumn{2}{r}{ Jumlah } & 32 & $100 \%$ \\
\hline
\end{tabular}

Untuk memberikan gambaran tentang kualitas dari materi Aplikasi Komputer 2 berdasarkan penilaian dari kedua ahli materi dapat dilihat pada Gambar 1.

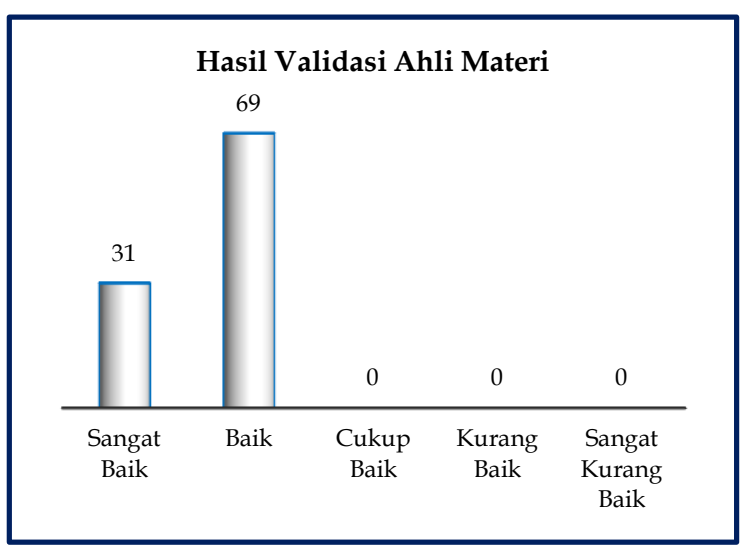

Gambar 1. Grafik Hasil Validasi dari Kedua Ahli Materi

Validasi ahli media dilakukan oleh dua orang dosen ahli media yang meliputi aspek lingkup pembelajaran dengan 4 aspek penilaian, informasi tambahan dengan 1 aspek penilaian, pertimbangan sikap pengguna dengan 1 aspek penilaian, hubungan pengguna dengan program (interface) dengan 5 aspek penilaian, navigasi dengan 3 aspek penilaian, pedagogi dengan 5 aspek penilaian, fitur tak tampak dengan 1 aspek penilaian, kehandalan program dengan 4 aspek penilaian. Berdasarkan perhitungan keseluruhan rerata hasil validasi dari kedua ahli media adalah 3,46 . Hasil ini menunjukkan bahwa kelayakan media e-learning ini adalah "Baik", sehingga dapat dilanjutkan ke tahap uji beta dengan terlebih dahulu melakukan revisi awal sesuai yang disarankan. Hasil tentang penilaian dari kedua ahli media dapat dilihat pada Tabel 4.

Tabel 4. Hasil Validasi Ahli Media

\begin{tabular}{clcc}
\hline No & \multicolumn{1}{c}{ Kategori } & Frekuensi & $\begin{array}{c}\text { Persentase } \\
(\%)\end{array}$ \\
\hline 1 & Sangat Baik & 1 & $2 \%$ \\
2 & Baik & 23 & $48 \%$ \\
3 & Cukup Baik & 21 & $44 \%$ \\
4 & Kurang Baik & 3 & $6 \%$ \\
5 & Sangat Kurang Baik & - & - \\
\hline \multicolumn{2}{c}{ Jumlah } & 48 & $100 \%$ \\
\hline
\end{tabular}

Untuk memberikan gambaran tentang kualitas dari media yang ada dalam $e$ learning berdasarkan penilaian oleh kedua ahli media dapat dilihat pada Gambar 2.

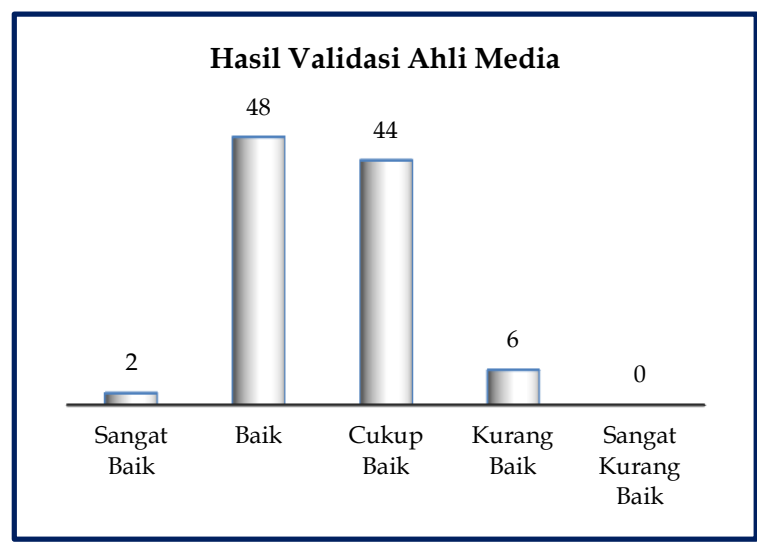

Gambar 2. Grafik Hasil Validasi dari kedua Ahli Media

Analisis dilakukan berdasarkan data yang diperoleh pada uji coba beta pada mahasiswa. Uji beta dilakukan pada mahasiswa Program Studi Pendidikan Sejarah sebanyak 3 orang, yaitu 1 orang yang berkemampuan tinggi, 1 orang berkemampuan sedang dan 1 orang berkemampuan rendah. Pemilihan mahasiswa dilakukan langsung oleh dosen pengajar Aplikasi Komputer 2 dengan melihat nilai Aplikasi Komputer 1 disemester ganjil. Data vali- 
dasi dari uji coba beta dapat dilihat pada lampiran. Rerata penilaian dan termasuk kategori "Baik". Informasi tentang penilaian dari mahasiswa dapat dilihat Tabel 5.

Tabel 5. Analisis Data Hasil dari Uji Beta

\begin{tabular}{llcc}
\hline No & \multicolumn{1}{c}{ Kategori } & Frekuensi & $\begin{array}{c}\text { Persentase } \\
(\%)\end{array}$ \\
\hline 1 & Sangat Baik & 20 & $33 \%$ \\
2 & Baik & 40 & $67 \%$ \\
3 & Cukup Baik & - & - \\
4 & Kurang Baik & - & - \\
5 & Sangat Kurang Baik & - & - \\
\hline \multicolumn{2}{r}{ Jumlah } & 60 & $100 \%$ \\
\hline
\end{tabular}

Untuk memberikan gambaran tentang kualitas dari produk yang ada dalam e-learning berdasarkan penilaian dari mahasiswa dapat dilihat pada Gambar 3.

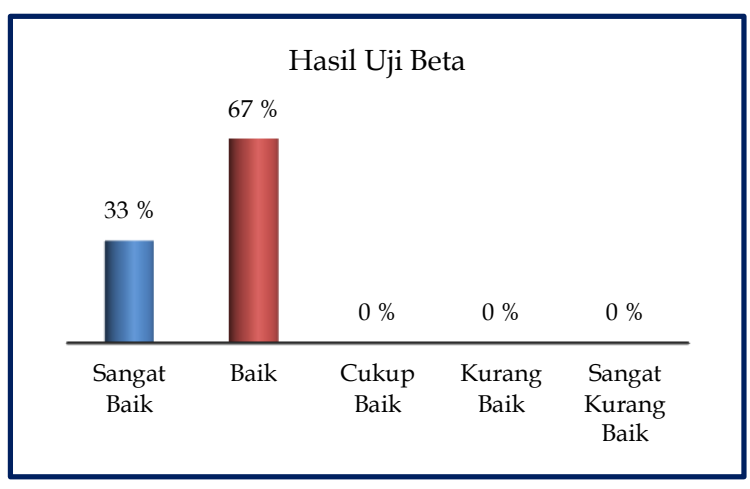

Gambar 3. Grafik Hasil Analisis Data Hasil dari Uji Beta

Setelah dilakukan evaluasi formatif, maka tahap selanjutnya melakukan evaluasi sumatif dengan uji coba yang melibatkan 16 orang mahasiswa dalam proses pembelajaran sebenarnya. Uji coba ini dimaksudkan untuk mengidentifikasi dan mengetahui kekurangan dari produk e-learning mata kuliah AK2, dan mengetahui efektivitas dalam pembelajaran. Hasil evaluasi sumatif yang ditunjukkan pada tabel 14, diketahui bahwa kualitas e-learning mata kuliah Aplikasi Komputer 2 yang dikembangkan tersebut, termasuk kriteria "Baik" dengan rerata 4,43, informasi mengenai penilaian mahasiswa pada evaluasi sumatif tersebut dapat dilihat pada Tabel 6 .

Untuk memberikan gambaran yang lebih jelas tentang kualitas produk e-learning mata kuliah Aplikasi Komputer 2 yang dikembangkan menurut penilaian dari mahasiswa pada evaluasi sumatif dapat dilihat pada Gambar 4.

Tabel 6. Distribusi Frekuansi Penilaian Evaluasi Sumatif

\begin{tabular}{|c|c|c|c|c|c|}
\hline No & & tegori & & Frekuensi & $\begin{array}{c}\text { Persentase } \\
(\%)\end{array}$ \\
\hline 1 & Sanga & & & 145 & $45 \%$ \\
\hline 2 & Baik & & & 166 & $52 \%$ \\
\hline 3 & Cukup & aik & & 9 & $3 \%$ \\
\hline 4 & Kuran & Baik & & - & - \\
\hline 5 & Sanga & urang & Baik & - & - \\
\hline & & & & 320 & $100 \%$ \\
\hline & $45 \%$ & $\begin{array}{l}\text { Hasil } \\
52 \%\end{array}$ & valuas & Sumatif & \\
\hline & & & $3 \%$ & $0 \%$ & $0 \%$ \\
\hline & $\begin{array}{c}\text { Sangat } \\
\text { Baik }\end{array}$ & Baik & $\begin{array}{c}\text { Cukup } \\
\text { Baik }\end{array}$ & $\begin{array}{c}\text { Kurang } \\
\text { Baik }\end{array}$ & $\begin{array}{c}\text { Sangat } \\
\text { Kurang } \\
\text { Baik }\end{array}$ \\
\hline
\end{tabular}

Gambar 4. Grafik Hasil Penilaian Kualitas e-learning Mata Kuliah AK2 dari

Mahasiswa

Analisis Keefektivan Hasil Belajar

Untuk melihat efektifitas penggunaan e-learning mata kuliah Aplikasi Komputer 2 dalam proses pembelajaran, maka dilakukan tes sumatif dengan memberikan pretest dan posttest pada mahasiswa. Proses yang dilakukan untuk mengukur pencapaian kompetensi mahasiswa secara berkelanjutan dalam proses pembelajaran dan menentukan keberhasilan belajar mahasiswa. (a) Analisis Keefektivan Hasil Belajar pada soal pilihan ganda. Berdasarkan tabel 7, mahasiswa yang mengikuti uji kompetensi dengan perolehan rerata pretest 57,38 dan rerata posttest 85,50 . Pretest dilakukan sebagai penjajakan penguasaan materi, sedangkan posttest dilakukan untuk mengetahui peningkatan hasil belajar yang ditinjau dari aspek kognitif. Dari data tersebut menunjukkan bahwa pengembangan e-learning mata kuliah Aplikasi Komputer 2 mempunyai efek yang positif untuk digunakan dalam pembelajaran dikampus, terbukti 
dengan perbandingan persentase pada hasil effect size berdasarkan pretest dan posttest. Dengan demikian ditinjau dari segi efektifitasnya maka pengembangan $e$ learning mata kuliah Aplikasi Komputer 2 yang dihasilkan adalah baik sebagai alat bantu atau pendukung dosen dalam pembelajaran. Untuk mengetahui hasil belajar mahasiswa digunakan effect size. Effect size merupakan ukuran mengenai besarnya efek suatu variabel pada variabel lain, besarnya perbedaan maupun hubungan, yang bebas dari pengaruh besarnya sampel. Nilai perubahan hasil belajar mahasiswa dari soal pilihan ganda dapat dilihat pada Tabel 7.

Tabel 7. Nilai Effect Size Hasil Pretest dan Posttest pada Soal Pilihan Ganda

\begin{tabular}{ccc}
\hline Pretest & Posttest & Effect size \\
\hline 57,38 & 85,5 & 28,13 \\
\hline
\end{tabular}

Tabel 7 menunjukkan adanya peningkatan pemahaman mahasiswa pada materi yang diberikan dengan skor pretest 57,38 dan posttest 85,5 , sehingga effect size adalah 28,13 . Effect size yang didapat, berupa nilai positif, sehingga terdapat perubahan pengetahuan mahasiswa yang lebih baik sesudah menggunakan e-learning sebagai media pembelajaran. Dari uji tersebut dapat dilihat bahwa terdapat perbedaan hasil pretest dan posttest, sehingga dapat ditarik kesimpulan bahwa hasil belajar mahasiswa dapat ditingkatkan secara signifikan dengan menggunakan media. Untuk memberikan gambaran lebih jelas tentang hasil belajar mahasiswa yang menggunakan e-learning mata kuliah Aplikasi Komputer 2 dapat dilihat pada Gambar 5 .

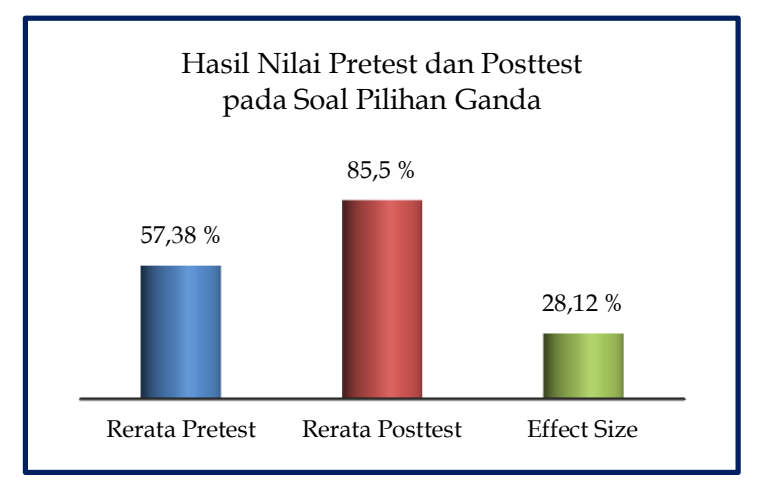

Gambar 5. Grafik Rerata Nilai Hasil Pretest dan Posttest
Pencapaian kompetensi seorang mahasiswa dapat dilihat dari keberhasilan mahasiswa tersebut mencapai nilai KKM (Kriteria Ketuntasan Minimal). Untuk KKM AK2 di Universitas Flores pada tahun ajaran 2012/2013 adalah 60. Mahasiswa dikatakan tuntas jika mencapai nilai $\geq 60$. Sehingga berdasarkan nilai yang didapatkan bahwa persentase ketuntasan belajar mahasiswa pada pretest $56,25 \%$ dan posttest $100 \%$. Untuk memberikan gambaran lebih jelas tentang ketuntasan hasil belajar mahasiswa yang menggunakan e-learning dapat dilihat pada Gambar 6.

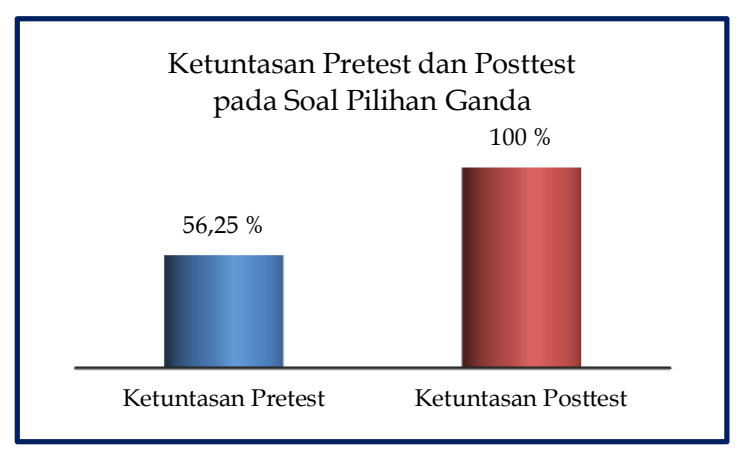

Gambar 6. Grafik Hasil Ketuntasan pretest dan posttest pada Tes Soal Pilihan Ganda

Analisis Keefektivan Hasil Belajar pada Soal Praktikum

Berdasarkan hasil 16 mahasiswa yang mengikuti uji kompetensi dengan perolehan rerata nilai praktikum pretest KD1 70,31, posttest KD1 84,06, pretest KD2 55,31, posttest KD2 85,31, pretest KD3 53,44, dan posttest KD3 84,06. Pretest dilakukan sebagai penjajakan penguasaan materi, sedangkan posttest dilakukan untuk mengetahui peningkatan hasil belajar praktikum. Dari data tersebut menunjukkan bahwa pengembangan e-learning mata kuliah Aplikasi Komputer 2 mempunyai efek yang positif untuk digunakan dalam pembelajaran dikampus, terbukti dengan perbandingan presentase pada hasil effect size berdasarkan pretest dan posttest. Dengan demikian ditinjau dari segi efektifitasnya maka $e$ learning mata kuliah Aplikasi Komputer 2 yang dihasilkan adalah baik sebagai alat bantu atau pendukung dosen dalam pembelajaran. Untuk mengetahui hasil belajar mahasiswa digunakan effect size. Nilai 
perubahan hasil belajar mahasiswa dari soal praktikum dapat dilihat pada tabel 8 .

Tabel 8. Nilai Effect Size Hasil Pretest dan Posttest pada Soal Praktikum

\begin{tabular}{lccc}
\hline & KD 1 & KD 2 & KD 3 \\
\hline Pretest & 70,31 & 55,31 & 53,44 \\
Posttest & 84,06 & 85,31 & 84,06 \\
Effect Size & 13,75 & 30 & 30,62 \\
\hline
\end{tabular}

Tabel 8 menunjukkan adanya peningkatan pemahaman mahasiswa pada materi yang diberikan dengan skor pretest KD1 70,31 dan posttest KD2 84,06, sehingga effect size adalah 13,75. Pretest KD2 55,31 dan posttest KD2 85,31, sehingga effect size adalah 30. Pretest KD3 53,44 dan posttest KD3 84,06, sehingga effect size adalah 30,62. Effect size yang didapat, berupa nilai positif, sehingga terdapat perubahan pengetahuan mahasiswa yang lebih baik sesudah menggunakan e-learning sebagai media pembelajaran. Dari uji tersebut dapat dilihat bahwa terdapat perbedaan hasil pretest dan posttest, sehingga dapat ditarik kesimpulan bahwa hasil belajar mahasiswa dapat ditingkatkan secara signifikan dengan menggunakan e-learning mata kuliah Aplikasi Komputer 2 sebagai media pembelajaran. Untuk memberikan gambaran lebih jelas tentang hasil belajar pada tes praktikum dapat dilihat pada Gambar 7.

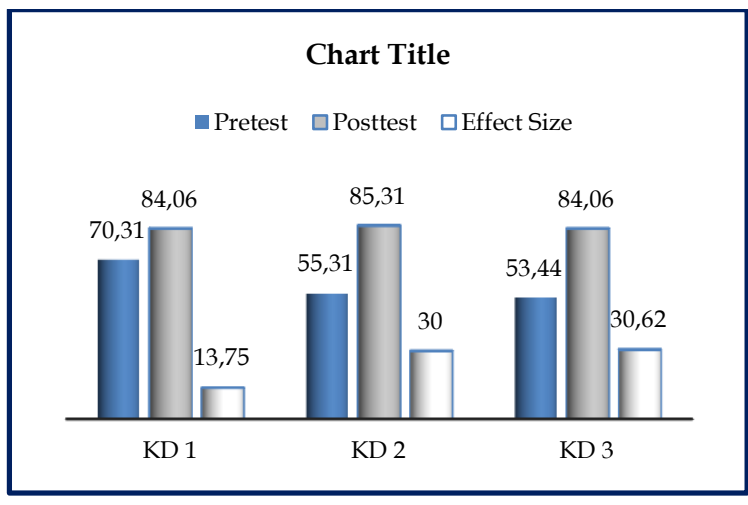

Gambar 7. Grafik Rerata Nilai Hasil Pretest dan Posttest pada Tes Praktikum

Pencapaian kompetensi seorang mahasiswa dapat dilihat dari keberhasilan mahasiswa tersebut mencapai nilai KKM di
Universitas Flores pada tahun ajaran 2012/ 2013 yaitu $\geq 60$. Sehingga berdasarkan nilai yang didapatkan bahwa persentase ketuntasan belajar mahasiswa pada pretest KD1 $81,25 \%$, posttest $\mathrm{KD} 1100 \%$, pretest $\mathrm{KD} 2$ $43,75 \%$, posttest KD2 $100 \%$, pretest KD3 $12,50 \%$, dan posttest KD3 100\%. Untuk memberikan gambaran lebih jelas tentang ketuntasan hasil belajar pada tes praktikum dapat dilihat pada Gambar 8.

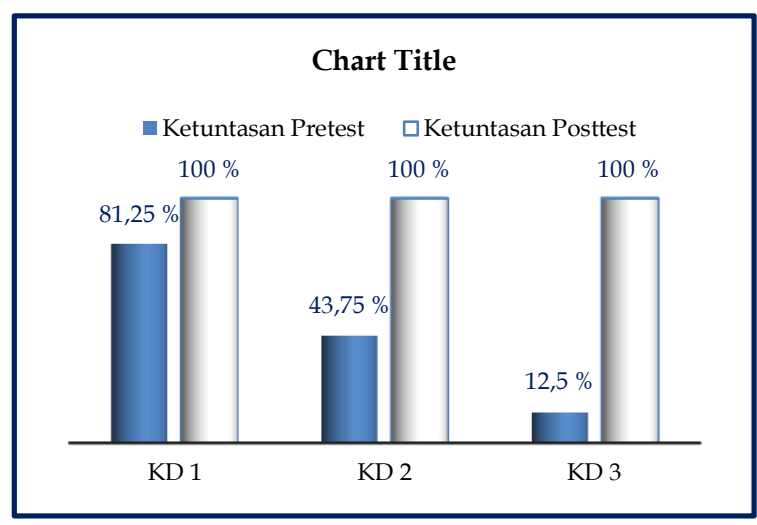

Gambar 8. Grafik Hasil Ketuntasan Pretest dan Posttest pada Tes Praktikum

\section{Kajian Produk Akhir}

Pengembangan e-learning mata kuliah AK2 melalui tahap perencanaan, desain dan pengembangan. Tujuan pengembangan yang mengacu pada tahap-tahap tersebut adalah agar pembelajaran menggunakan e-learning mata kuliah AK2 yang dihasilkan benar-benar layak dan efektif digunakan dalam pembelajaran. Berdasarkan analisis data, maka dapat diambil beberapa kesimpulan, yaitu: Hasil penilaian dari kedua ahli materi pada uji alfa terhadap kelayakan materi AK2 yang dikembangkan adalah "Baik". Hal ini berdasarkan pada perolehan skor rerata yang mencapai 4,31 dengan kategori baik. Berdasarkan hasil ini pula, maka e-learning mata kuliah AK2 dinyatakan "layak" untuk digunakan dalam pembelajaran AK2.

Hasil penilaian dari kedua ahli media pada uji alfa terhadap kelayakan media e-learning mata kuliah AK2 adalah "Baik". Hal ini berdasarkan pada perolehan skor rerata yang mencapai 3,46 dengan kategori baik. Berdasarkan hasil ini pula, maka pengembangan e-learning mata kuliah AK2 
dinyatakan "layak" untuk digunakan dalam pembelajaran AK2.

Hasil penilaian dari mahasiswa pada uji beta terhadap kelayakan media dan materi AK2 yang dikembangkan dalam $e^{-}$ learning adalah "Baik". Hal ini berdasarkan pada perolehan skor rerata yang mencapai 4,33 dengan kategori baik. Berdasarkan hasil ini pula, maka pengembangan e-learning mata kuliah AK2 dinyatakan "layak" untuk digunakan dalam pembelajaran AK2.

Hasil penilaian dari mahasiswa pada uji coba program terhadap kelayakan media dan materi yang dikembangkan dalam e-learning pada mata kuliah AK2 adalah "Baik". Hal ini berdasarkan pada perolehan skor rerata yang mencapai 4,43 dengan kategori baik. Berdasarkan hasil ini pula, pengembangan e-learning mata kuliah AK2 dinyatakan "layak" untuk digunakan dalam pembelajaran AK2.

Hasil pretest dan posttest mahasiswa menunjukkan bahwa pengembangan elearning mata kuliah AK2 lebih efektif digunakan dalam pembelajaran. Hal ini dibuktikan dengan perolehan rerata pretest 57,38 dan rerata posttest 85,50 , sehingga hasil effect size adalah 28,13 . Keefektivan juga dilihat dari hasil tes praktikum dengan rerata pretest KD1 70,31 dan posttest KD1 84,06 , sehingga effect size adalah 13,75. Pada pretest KD2 55,31 dan posttest KD2 85,31, sehingga effect size adalah 30 . Kemudian pada pretest KD3 53,44 dan pretest KD3 84,06 , sehingga effect size adalah 30,62. Berdasarkan data tersebut terlihat bahwa menggunakan e-learning mata kuliah AK2 lebih efektif untuk meningkatkan hasil belajar mahasiswa.

\section{Simpulan}

Produk yang dikembangkan dalam penelitian ini berupa e-learning mata kuliah Aplikasi Komputer 2 dengan alamat www. e-uniflor.web.id/elearning. Bisa diakses dengan menggunakan komputer yang terkoneksi dengan jaringan internet. Untuk masuk ke course Aplikasi Komputer 2, mahasiswa atau pengguna baru harus login. Materi yang dikembangkan pada bahan ajar AK 2 sebagai berikut: (1) membuat presentasi menggunakan Microsoft Powerpoint 2007; (2) membuat media pembelajaran interaktif dengan menggunakan Microsoft Powerpoint 2007; dan (3) membuat kuis interaktif atau evaluasi pembelajaran dengan menggunakan Microsoft Powerpoint 2007.

Kualitas media pembelajaran dengan e-learning pada mata kuliah Aplikasi Komputer 2 yang dihasilkan termasuk ke dalam kategori baik dan layak digunakan berdasarkan uji kelayakan dari aspek materi dengan skor 4,31 dari aspek media dengan skor 3,46, dan tanggapan mahasiswa dengan skor 4,43.

Keefektifan pembelajaran Aplikasi Komputer 2 menggunakan e-learning terbukti secara signifikan dapat meningkatkan hasil belajar kognitif mahasiswa dengan rerata pretest 57,38 dan posttest 85,50 sehingga perolehan hasil effect size adalah 28,13. Pencapaian ketuntasan hasil belajar pada saat pretest $56,25 \%$ tuntas dan saat posttest $100 \%$ tuntas. Keefektifan juga dilihat dari hasil tes praktikum dengan rerata pretest KD1 70,31 dan posttest KD1 84,06, sehingga effect size adalah 13,75. Pada pretest KD2 55,31 dan posttest KD2 85,31, sehingga effect size adalah 30 . Kemudian pada pretest KD3 53,44 dan pretest KD3 84,06, sehingga effect size adalah 30,62. Persentase ketuntasan belajar mahasiswa dari tes praktikum pada pretest KD1 81,25\% tuntas, posttest KD1 100\% tuntas, pretest KD2 43,75\% tuntas, posttest KD2 100\% tuntas, pretest KD3 12,50\% tuntas, dan postest KD3 $100 \%$ tuntas.

Saran

Saran pemanfaatan produk yang dikembangkan adalah sebagai berikut: (1) media pembelajaran mata kuliah Aplikasi Komputer 2 telah memenuhi kriteria baik, dan efektif, sehingga layak digunakan pada pembelajaran di kelas; dan (2) disarankan kepada dosen untuk membuat course sesuai dengan mata kuliah yang diampu. 


\section{Daftar Pustaka}

Alessi, S.M., \& Trollip, S.R. (2001). Multimedia for learning methods and development (3 $r d \mathrm{Ed})$. Massachusetts: Allyn \& Bacon.

Agung, S. (2010). Studi deskriptf effect size penelitian-penelitian di fakultas psikologi universitas sanata dharma. Jurnal Penelitian Sanata Dharma, 20, 1-17.

Clark, R.C,. \& Mayer, R.E. (2011). E-learning and the science of instruction: proven guidelines for consumers and designers of multimedia learning ( $3 \mathrm{rd} E d$ ). United Stated of Amerika.
Daryanto. (2010). Media Pembelajaran. Yogyakarta: Gava Media.

Lee, W.W., \& Owens, D.L. (2005). Multimedia-based instructional desaign (2nd $E d)$. San Francisco: Pfeifer.

Rusman., Kurniawan, D., \& Riyana, C. (2012). Pembelajaran berbasis teknologi informasi dan komunikasi. Jakarta: Rajagrafindo Persada.

Sukardjo. (2006). Desain pembelajaran: Evaluasi pembelajaran. Handout Perkuliahan : PPs UNY.

Surjono, H.D. (2010). Membangun course elearning berbasis moodle. Yogyakarta: UNY PRES. 